\title{
Learning Strategies at SMP Muhammadiyah 2 Taman during the Covid 19 Pandemic [Strategi Pembelajaran SMP Muhammadiyah 2 Taman Saat Pandemi Covid
} 19]

\author{
Syilviana Eka Purwanto *, Muhlasin Amrullah \\ \{ silvianaekapurwanto30@gmail.com, muhlasin1@umsida.ac.id\} \\ Fakultas Psikologi dan Ilmu Pendidikan, Universitas Muhammadiyah Sidoarjo, Indonesia
}

\begin{abstract}
This study aims to determine the learning strategies during the pandemic at SMP Muhammadiyah 2 Taman, namely learning from home or distance learning. This research uses descriptive qualitative method. The results of this study indicate that the implementation of online learning during the Covid19 pandemic has various problems experienced by teachers, students, and parents. The problems of teachers are in the form of weak mastery of IT and limited access to supervision of students, from students in the form of inactivity in participating in online learning, limited supporting facilities and internet network access, while parents have limited time to accompany their children during online learning.
\end{abstract}

Keywords: The Impact of Covid-19, Learning Strategies, Education

\begin{abstract}
Abstrak. Penelitian ini bertujuan untuk mengetahui strategi pembelajaran saat pandemi di SMP Muhammadiyah 2 Taman yaitu belajar dari rumah atau pembelajaran jarak jauh. Penelitian ini menggunakan metode kualitatif deskriptif. Hasil penelitian ini memberitahukan bahwasanya pelaksanaan untuk pembelajaran daring di selama pandemi covid-19 mempunyai beragam problematika yang dialami oleh guru, peserta didik, dan orang tua. Permasalahan dari guru berupa lemahnya penguasaan teknologi dan terbatasnya akses pengawasan peserta didik, dari peserta didik berupa ketidakaktifan mengikuti pembelajaran daring, keterbatasan fasilitas yang mendukung dan akses jaringan internet, sementara itu dari orang tua memiliki keterbatasan waktu dalam mendampingi anaknya di saat pembelajaran daring.
\end{abstract}

Kata Kunci: Dampak Covid-19, Strategi Pembelajaran, Pendidikan

\section{Pendahuluan}

Saat diumumkan oleh pemerintah mengenai kasus pertama yaitu Covid-19 pada bulan Maret 2020 tahun lalu. Sehingga berdampak pada semua aspek kehidupan mulai dari ekonomi, pendidikan, dan kesehatan. Pada sektor pendidikan, pemerintah melalui Kemendikbud (Kementerian Pendidikan dan Kebudayaan) menerapkan kebijakan tentang pembelajaran jarak jauh. Situasi ini mengacu kepada Keputusan Bersama Menteri Pendidikan dan Kebudayaan, Menteri Agama, Menteri Kesehatan dan Menteri Dalam Negeri tentang Panduan Penyelenggaraan Pembelajaran pada Tahun Ajaran 2020/2021 dan Tahun Akademik 2020/2021 di masa Covid-19. Berdasarkan Undang-Undang Perguruan Tinggi nomer 12 tahun 2012, pasal 
31 tentang Pendidikan Jarak Jauh (PJJ) menjelaskan bahwa PJJ merupakan proses belajar mengajar yang dilakukan secara jarak jauh melalui penggunaan berbagai media komunikasi. Belajar dari rumah itu sama halnya dengan belajar di sekolah, walaupun pada saat pembelajaran tidak langsung tatap muka melainkan menggunakan pihak ketika seperti zoom dan lain lain. Kemudian, setelah melakukan pengamatan di masyarakat, sebagaian masyarakat masih belum memiliki hp atau laptop untuk menunjang proses kegiatan belajar dari rumah. Selain itu beberapa guru juga masih belum paham betul dengan teknologi. Peralihan sistem dalam belajar konvensional ke sistem daring secara mendadak akibat pandemi menyebabkan ketidaksiapan yang matang. Beberapa halangan tersebut terjadi secara serentak di seluruh wilayah Indonesia. Salah satunya di kota Sidoarjo yang termasuk mengikuti anjuran pemerintah yaitu belajar dari rumah. Dari hasil diatas tersebut bahwasanya dapat dipahami bahwa pembelajaran online atau daring merupakan solusi yang sangat efektif untuk pembelajaran selama pandemi covid 19 ini. Walaupun dapat memunculkan beberapa masalah dari guru, peserta didik, murid, orang tua atau instansi pendidikan.[1]

\section{Metode Penelitian}

Penelitian ini menggunakan metode penelitian kualitatif deskriptif. Pendekatan kualitatif merupakan proses penelitian untuk memahami masalah-masalah sosial atau manusia dengan menganalisis kata-kata untuk menciptakan gambaran kompleks dan menyeluruh, serta melaporkan pandangan informasi terperinci yang diperoleh dari para sumber informasi dalam lingkungan alami. Pendekatan kualitatif juga bertujuan untuk menyelidiki, menemukan, menggambarkan, serta menjelaskan kualitas atau keistimewaan dari pengaruh sosial yang tidak dapat dijelaskan, diukur, atau digambarkan melalui pendekatan kuantitatif. Teknik pengambilan data dalam penelitian ini melalui wawancara, dokumentasi dan observasi, adapun trianggulasi yang di pakai dalam penelitian ini adalah trianggulasi teknik. Penggunaan metode kualitatif ini dimaksudkan untuk memperoleh gambaran mengenai strategi SMP Muhammadiyah 2 Taman dalam pembelajaran di tengah pandemi covid 19 untuk semua kelas.

\section{Hasil dan Pembahasan}

Bermula dari semangat perubahan dan keluar dari kolonialisme Belanda, di sinilah muncul berbagai konsep-konsep pendidikan kebangsaan seperti pribumi, rakyat dan nasionalis. Berfungsi untuk mencerdaskan bangsa dan mengobarkan semangat nasionalisme. Menurut Soegarda Poerbakawatja dalam buku Mohamad Ali menyebutkan bahwa tiga tokoh pribumi yang berani dan mampu merintis pendidikan moderen pada abad 20 yaitu K.H Ahmad Dahlan (1868-1923) dengan mendirikan Muhammadiyah sebagai wadah pergerakanya pada tahun 18 November 1912, sepuluh tahun kemudian Ki Hadjar Dewantara (1889-1959) pada tahun 1922 mendirikan Perguruan Taman Siswa, kemudian disusul oleh Mohammad Sjafei (1893-1951) pada tahun 1926 merintis Ruang Pendidikan INS Kayu tanam. K.H. Ahmad Dahlan mendahulukan pengetasan pribumi muslim dari kebodohan dan dualitas pendidikan agama dan ilmu umum.[2] Ahmad Dahlan berhasil menyatukan dua ilmu yang bertentangan tersebut menjadi satu. Dimulai dari mengajarkan pembaharuan-pembaharuan dalam bidang astronomi ketika meluruskan arah kiblat masjid Keraton, memanfaatkan fasilitas bangku dan papan tulis dalam proses pembelajaran sampai dengan memasukan kurikulum pelajaran ilmu umum di sekolah yang diadakan oleh beliau, membentuk pemikiran pendidikan oleh K.H. Ahamd Dahlan yang merupakan pendiri konsep pendidikan Islam modern saat itu. Pada tahun 1911 K.H. Ahmad Dahlan dibantu oleh muridnya untuk mendirikan sekolah pertama yang kedepannya 
akan menjadi model sekolah modern Muhammadiyah yaitu Madrasah Ibtidaiyah Diniyah Islamiyah (Steenbrink, 1994: 52). Muhammadiyah terus maju dan berkembang ke seluruh pelosok tanah air dengan berbekal iman dan amal shaleh. Beraneka ragam tantangan dan rintangan yang datang selalu dihadapi dengan sabar dan tawakkal. Atas keuletan seluruh pendukungnya, makaakhirnya. Muhammadiyah berhasil membawa kebesaran nama dan keleluasaan gerakannya. Contohnya di kota dan kabupaten Sidoarjo pun banyak sekali sekolahsekola Muhammadiyah yaitu mulai dari TK, SD, SMP, MTs, MA, dan SMA.[3]

Dalam Kamus Besar Bahasa Indonesia, strategi berarti rencana yang cermat mengenai kegiatan untuk mencapai sasaran khusus. Dihubungkan dengan belajar mengajar, strategi bisa diartikan sebagai pola umum kegiatan guru dan peserta didik dalam perwujudan kegiatan belajar mengajar untuk mencapai tujuan yang digariskan. Menurut Hamalik [4] mengatakan bahwa: Strategi pengajaran adalah keseluruhan metode dan prosedur yang menitikberatkan pada kegiatan siswa dalam proses belajar mengajar untuk mencapai tujuan tertentu. Didasarkan UU No. 20 Tahun 2003, pasal 20 tentang Sistem Pendidikan Nasional dan berdasarkan pasal 24 (2) sisdiknas tersebut tentang Otonomi Perguruan Tinggi menyatakan dalam pasal 24 tersebut bahwa Perguruan Tinggi untuk mengelola sendiri lembaganya sebagai pusat penyelenggaraan Perguruan Tinggi, penelitian ilmiah, dan pengabdian kepada masyarakat. SMP Muhammadiyah 2 Taman pada saat ini melakukan pembelajaran dengan sistem jarak jauh, karena hingga saat ini masih belum di perbolehkan untuk belajar secara tatap muka. Tapi walaupun tidak bisa belajar dengan tatap muka setidaknya masih bisa ke sekolah. Menurut ibu Evi selaku narasumber dan sebagai guru di mata pelajaran bahasa Inggris di SMP Muhammadiyah 2 Taman mengatakan bahwasanya metode pembelajaran di rumah atau bisa disebut dengan pembelajaran daring ini untuk semua kelas tidak hanya kelas 8 atau lelas 9, melainkan untuk semuanya rata dengan sistem full daring. Media yang digunakan untuk pembelajaran adalah dengan pihak ketiga yaitu zoom, Google Meet dan Google Classroom. Tapi yang paling sering digunakan yaitu aplikasi Zoom karena sudah terbiasa. Ketika pengumpulan tugas atau absen biasanya menggunakan secara manual atau dengan whatsapp. Peserta didik masih tetap di rumah sedangkan guru di SMP Muhammadiyah 2 Taman tetap mengajar di sekolah. Namun apabila gurunya mengalami kendala sakit misalnya bisa bekerja di rumah atau mengajar di rumah. Untuk beberapa bulan terakhir ini 5 atau 6 bulan terakhir memang agak sedikit spesial karena siswa tidak semuanya memiliki fasilitas di rumah, kedua mereka memang tekun meskipun mereka belajar tanpa pengawasan orang tua. Tibatiba peserta didik yang awalnya tekun menjadi malas. Apabila memiliki rekam jejak absen sudah melebihi 5 kali maka akan di panggil untuk belajar di sekolah.

SMP Muhammadiyah 2 Taman pernah memiliki program home visit yaitu para guru berkunjung kerumah siswa satu persatu, awalnya untuk anak-anak yang bermasalah yang sering absensi atau mungkin ketika guru menemukan siswa di sosial media berkata yang tidak baik, itulah alasannya mengapa diadakan program home visit. Tapi seiring berjalan nya waktu home visit ini di lakukan ke semua murid. Strategi pembelajaran di SMP Muhammadiyah 2 Taman sangat berbeda pada saat pandemi. Seperti yang diketahui saat pandemi ini pembelajaran dilakukan secara jarak jauh. Hal ini tentu saja membuat para guru dan peserta didik mengalami situasi yang tak terduga. [5] Kegiatan belajar mengajar harus dipersiapkan secara matang seperti memilih dengan apa mereka belajar, membuat materi, memilih aplikasi yang sman dan mudah diakses oleh semua murid. Untuk mendapatkan hasil belajar yang optimal, guru dituntut untuk lebih kreatif dan membangkitkan motivasi belajar pada siswa. Terlebih dalam situasi pandemi saat ini tentunya motivasi belajar pada siswa memang harus benar-benar ditanamkan sedemikian rupa karena pembelajaran daring yang sudah berlangsung cukup lama ini tentunya 
menimbulkan kejenuhan dan kurangnya semangat belajar pada siswa. Dua minggu sebelum ujian sekolah para peserta didik kelas 9 menjalani luring atau belajar langsung di sekolah.

\section{Kesimpulan}

Dari hasil penelitian, dapat disimpulkan bahwa pembelajaran tatap muka di kondisi pandemi Covid-19 dapat dilakukan dengan perencanaan yang matang. Dimulai dari penyusunan RPP yang dibuat seusai dengan kondisi pandemi covid-19,pelaknaan pembelajaran yang diatur sesuai dengan rencana yang telah dibuat begitu pula dengan evaluasi atau penilian. RPP dibuat guru secara mandiri, dengan pelatihan serta diskusi dalam Kelompok Kerja guru sehingga tersusun lah RPP yang cocok digunakan pada saat pandemi covid-19. Pelaksanaan pembelajaran dilakukan dengan membagi shif kelas agar tidak menyalahi aturan pemerintah dan proses pembelajaran tetap berlangsung. Strategi pembelajaran yang digunakan oleh SMK Muhamamdiyah 1 Taman cukup efektif karena sekolah ini merupakan sekolah kejuruan yang sangat membutuhkam praktek secara langsung dengan bertatap muka.

\section{Ucapan Terima Kasih}

Dengan terselesaikannya Karya Ilmiah ini penulis mengucapkan terima kasih yang sedalam dalamnya kepada Allah S.W.T atas limpahan karunia dan hidayahnya sehingga penulis dapat melaksanakan penelitian dan menyelesaikan Karya Ilmiah. Bapak dan ibu guru SMP Muhammadiyah 2 Taman, yang telah memberikan izin dan bersedia untuk diwawancarai. Teman-teman yang saling membantu dan mendukung dalam mengerjakan Karya Ilmiah ini dan atas kerjasamanya.

\section{References}

[1] Alfiah, R. (2020). Strategi guru dalam pembelajaran pai pada masa pandemi covid 19 di SMPN 2 Katingan Hilir (Doctoral dissertation, IAIN Palangka Raya).

[2] Asmuni, A. (2020). Problematika Pembelajaran Daring di Masa Pandemi Covid-19 dan Solusi Pemecahannya. Jurnal Paedagogy,7(4), 281-288.

[3] Mansyur, A. R. (2020). Dampak covid-19 terhadap dinamika pembelajaran di indonesia. Education and learning journal, 1(2), 113-123.

[4] Syaifuddin, M. A., Anggraeni, H., Khotimah, P. C., \& Mahfud, C. (2019). Sejarah Sosial Pendidikan Islam Modern Di Muhammadiyah. TADARUS, 8(1).

[5] Utaminingsih, S., Sumanto, D., Haryanti, A., Prastini, E., \& Kurniawan, F. (2021). Strategi Meningkatkan Motivasi Belajar Siswa Selama Pademi Covid19 Di SMP Islam Nurulhidayah Komplek Perumahan Renijaya Utama, Podok Petir, Bojongsari, Depok Tahun 2020. Abdi Laksana:Jurnal Pengabdian Kepada Masyarakat, 2(1), 7-14. 